\title{
Reproductive performance of multiparous rabbit lactating does: effect of lighting programs and PMSG use
}

\author{
Luis Quintela $^{\mathrm{a} *}$, Ana PeÑA ${ }^{\mathrm{a}}$, Mónica BARrio ${ }^{\mathrm{a}}$, \\ Maria Dolores VEGA ${ }^{\mathrm{b}}$, Roberto DiAZ ${ }^{\mathrm{a}}$, Francisco MASEDA ${ }^{\mathrm{c}}$, \\ Pedro GARCIA ${ }^{\mathrm{a}}$ \\ ${ }^{a}$ Unit of Reproduction and Obstetrics, Department of Animal Pathology, \\ Faculty of Veterinary Medicine, University of Santiago de Compostela, 27002 Lugo, Spain \\ b COGAL, S.L., Rodeiro, Pontevedra, Spain \\ ${ }^{c}$ Department of Agroforestry Engineering, Superior Politechnique School, \\ University of Santiago de Compostela, 27002 Lugo, Spain
}

(Received 26 February 2001; accepted 22 May 2001)

\begin{abstract}
This study aims to determine if Pregnant Mare Serum Gonadotrophin (PMSG), used for oestrous synchronization in multiparous lactating does, could be replaced by one of the following lighting schedules without impairing reproductive performance: (a) 12-h L (light)/12-h D (dark) or (b) 8-h L/16-h D, until day 6 before artificial insemination (AI), when in both cases photoperiod was changed to $16-\mathrm{h} \mathrm{L} / 8-\mathrm{h}$ D and maintained until the day of $\mathrm{AI}$, and in the following 4 days post $\mathrm{AI}$ the light hours were progressively reduced to the initial schedules. Two groups of 20 does each were respectively submitted to one of the lighting schedules specified above. All does were artificially inseminated in 6 consecutive cycles at 42 days intervals. In the first, third and fifth AIs, PMSG (20 IU/ doe via sc $48 \mathrm{~h}$ before $\mathrm{AI}$ ) was used in the two groups of does, whereas in the second, fourth and sixth AIs no hormonal treatment was used. Degree of oestrous synchronization (also referred in text as sexual receptivity) was estimated by the colour of the vulva at AI. Reproductive performance of does was evaluated based on fertility (kindling rates), prolificity, mortality at birth, mortality at 21 days post birth, weight of the litter at 21 days post birth and number of weaned rabbits. Oestrous was better synchronized when PMSG was used with any of the two lighting programs. Without using PMSG, a photoperiod of 12-h L/12-h D until 6 days before AI resulted in a better sexual receptivity of does than 8-h L/16-h D. Fertility, prolificity, mortality of young rabbits at 21 days, the weight of the litters at 21 days and the number of weaned rabbits did not vary with the lighting program and were not affected by the PMSG treatment. Mortality at birth, however, was higher $(+1$ dead kit per litter) in litters housed under a light program of 12-h L/12-h D. Global productivity (number of weaned rabbits per 100 inseminated does) was better when using PMSG, for both lighting schedules. When using a
\end{abstract}

* Correspondence and reprints

E-mail: laquiari@correo.lugo.usc.es 
photoperiod of 12-h L/12-h D until 6 days before AI, and omitting the PMSG treatment, global productivity was scarcely reduced, however, it was considerably impaired when using a photoperiod of 8-h L/16-h D until 6 days before AI and no PMSG treatment.

rabbit (Oryctolagus cuniculus) / PMSG / photoperiod / reproductive performance

Résumé - Performances de reproduction des lapines multipares allaitantes : effet de régimes lumineux et de l'emploi de PMSG. L'utilisation de programmes lumineux pour remplacer l'emploi de PMSG a été éprouvée pour la synchronisation de lapines multipares allaitantes. Deux groupes de 20 lapines ont été soumises à l'un des deux régimes suivants : (a) 12 heures d'éclairage et 12 heures d'obscurité par jour (12L/12D) et (b) 8 heures de lumière et 16 d'obscurité (8L/16D). Dans les deux cas, 6 jours avant et jusqu'à l'insémination artificielle (IA), le régime a été modifié pour avoir 16 heures de lumière artificielle par jour. Les 4 jours suivants l'IA, la durée d'éclairage a été progressivement changée pour retourner à la situation initiale. Toutes les femelles ont été inséminées lors de 6 cycles successifs à 42 jours d'intervalle. Quarante huit heures avant $1 \mathrm{a} 1^{\mathrm{e}}, 3^{\mathrm{e}}$ et $5^{\mathrm{e}} \mathrm{IA}$, 20 UI de PMSG ont été administrées par voie sous-cutanée aux lapines des deux groupes. Cette stimulation hormonale n'a pas été faite aux $2^{\mathrm{e}}, 4^{\mathrm{e}}$ et $6^{\mathrm{e}}$ IA. Le degré de synchronisation (ou réceptivité) a été évalué par la couleur de la vulve au moment de l'IA. Les performances reproductives ont été déterminées par la fertilité (taux de mise bas), la prolificité, la mortinatalité et la mortalité 21 jours après mise bas, le poids de la portée à 21 jours et le nombre de lapereaux sevrés par portée. Les résultats montrent que la réceptivité a été mieux synchronisée avec PMSG quel que soit le régime lumineux. Sans PMSG, la réceptivité a été meilleure sous $12 \mathrm{~L} / 12 \mathrm{D}$ que sous $8 \mathrm{~L} / 16 \mathrm{D}$. La fertilité, la prolificité, la mortalité des lapereaux à 21 jours, le poids de la portée à 21 jours et le nombre de lapereaux sevrés n'ont pas été modifiés par le régime lumineux ni par le traitement à la PMSG. Cependant la mortinatalité a été supérieure (plus d'un lapereau par mise-bas) chez les animaux qui ont reçu le programme 12L/12D. La productivité (nombre de lapereaux sevrés pour 100 lapines inséminées) fut meilleure avec PMSG pour chacun des traitements lumineux. Avec 12L/12D et sans PMSG, la productivité n'a pas été réduite de façon importante. Cependant, elle a été clairement affectée avec le régime 8L/16D sans PMSG.

lapereau (Oryctolagus cuniculus) / PMSG / programme lumineux / fertilité / prolificité

\section{INTRODUCTION}

Artificial insemination in rabbits is commonly practised in European countries, being currently used in around $30 \%$ of the Spanish rabbit farms. The use of AI enables cycled production systems to be applied, and therefore, a better and economical production to be obtained. Intensive and semiintensive cycled production systems are based on the insemination of females few days after parturition (from 0 to 11 days), which means that such a high reproductive efficiency implies inseminating most of the females during lactation, probably not being sexually receptive due to the antagonism between prolactin and gonadotrophins secretion. Therefore, oestrous has to be induced and synchronized in lactating does to warrant an acceptable reproductive performance.

The use of hormonal treatments for oestrous induction and synchronization is a common practice in industrial rabbit breeding. The very potent compound (PMSG) obtained from serum of pregnant mares is the most widely used hormone for lactating does [10]. Some authors have reported its efficiency to increase sexual receptivity, fertility, prolificity and thus, productivity. However, since PMSG is a large molecule, exogene for the rabbit, that molecule is consequently suspected to cause an inmunologic or refractory response 
to repeated injections $[6,9]$. A clear positive effect of PMSG was found to be limited to the first 4 cycles of insemination in lactating does [19], although a dose response effect may be involved in this process. PMSG doses commonly used in commercial rabbit farms (20-25 IU) probably exceed the minimal dose needed for improving productivity in lactating does [23], and the lower the PMSG dose and the number of injections, the minor the immune response [24].

A tendency to investigate the use of alternative methods, other than hormonal treatments, for oestrous synchronization in does, has been prompted by the belief that, in the near future, the EC policy will determine a restriction on the use of hormones regarding meat residues, animal welfare and the exigence to maintain a natural image of rabbit meat [10]. Over the last years, considerable efforts have been dedicated to the study of biostimulation methods, which do not involve the use of hormones, in an attempt to improve sexual receptivity and reproductive performance of lactating does. One of the biostimulation methods more frequently investigated is the use of lighting programs, yet the underlying physiological mechanisms are still poorly understood [18]. Wild rabbits (Oryctolagus cuniculus) have a seasonal reproduction cycle, with long days stimulating sexual activity. In European latitude, most of the pregnancies occur between February and early August, with a peak in May [7, 11]. In commercial rabbit farms there is practical evidence of a seasonal influence, which decreases reproduction efficiency during the short-day seasons [17]. Studies approaching photoperiod manipulation in rabbit farms have generally shown a significant improvement of does receptivity and fertility when the daylight length was artificially increased [12].

The aim of the present study was to find out if a PMSG treatment applied to multiparous lactating does could be replaced by one of two lighting programs (12-h L/ 12-h D or 8-h L/16-h D of continuous photoperiods until day 6 before AI, when in both cases photoperiod was suddenly changed to $16-\mathrm{h} \mathrm{L} / 8-\mathrm{h} \mathrm{D})$ without negatively affecting the does reproductive performance.

\section{MATERIALS AND METHODS}

\subsection{Animals}

Forty commercial hybrid does (Hyplus strain PS19, Grimaud Frères, France) of approximately 30 weeks of age (secondiparous) were initially used. The does, belonging to an industrial rabbit farm (COGAL SL, Pontevedra, Spain), were housed at the Veterinary Faculty of Lugo for the 9-month experimental period (from February to December 1999). Animals were randomly divided in 2 groups of 20 does each and located in 2 identical windowless experimental rooms. In both rooms, a forced ventilation system was used and the inside temperature was maintained between 18 and $22{ }^{\circ} \mathrm{C}$ by using an air conditioned-heater system. Light intensity was 70 lux in the two rooms, but a different lighting schedule was used in each one (A or B groups, respectively, specified below). All does were individually housed in flat deck cages $\left(0.3 \mathrm{~m}^{2}\right)$ communicated through a circular hole with external nests $\left(0.12 \mathrm{~m}^{2}\right)$ which could be closed by a sliding door. Does who died during the experiment or were discarded were immediately replaced by does of the same age, parity, and physiological status, belonging to the original farm.

Pregnant or lactating does were fed ad libitum whereas non-pregnant nonlactating does were restricted to $150 \mathrm{~g} \cdot \mathrm{day}^{-1}$ of commercial feed except in the period from day 6 before AI to the day of pregnancy diagnosis, during which they were also fed ad libitum. Two types of commercial diets were used: from 21 days post partum to weaning (30-35 days), all does, for practical reasons including non lactating females, were fed with a kits-suitable commercial feed $(15.3 \% \mathrm{CP}, 16.5 \% \mathrm{CF}$, 
$1800 \mathrm{kcal} \mathrm{DE})$, and during any other periods a maternity diet $(17.8 \% \mathrm{CP}, 13.3 \% \mathrm{CF}$, $2300 \mathrm{kcal}$ DE) was used.

\subsection{Semen processing and artificial insemination}

Semen used for AI was obtained from an AI Center, belonging to COGAL SL, where routinely, rabbit semen was collected, diluted and stored at $16^{\circ} \mathrm{C}$ for using within a 24-h period.

Ejaculates from 8-12 males (Hyplus PS39, Grimaud Frères, France) were collected using artificial vagina, pooled and diluted with a commercial extender (MA 24, Ovejero, Leon, Spain) to a standard concentration of $60 \times 10^{6}$ spermatozoa $\cdot \mathrm{ml}^{-1}$. Only ejaculates with a free-gel volume higher than $0.2 \mathrm{~mL}$ and sperm mobility (subjective microscopic evaluation) higher than $70 \%$, were used.

Does were vaginally inseminated using disposable plastic pipettes, receiving a dose of $30 \times 10^{6}$ spermatozoa in a volume of $0.5 \mathrm{~mL}$. At the time of performing AI, vulva colour was recorded as white, pink, red or purple.

\subsection{Reproductive management}

All does were inseminated on the same day, at 42 days intervals (i.e. $11 \mathrm{~d}$ post partum), performing a total of $6 \mathrm{AI}$ on both, A and B groups. All the does were treated hormonally to synchronize the oestrus in the first, third and fifth AIs, whereas they were not treated in the second, fourth and sixth AIs. The hormonal treatment consisted of 20 IU PMSG (Follygon, Intervet, Salamanca, Spain), injected in a volume of $0.4 \mathrm{~mL}, 48 \mathrm{~h}$ before AI. Whether or not treated for oestrus synchronization, all does were induced to ovulate by injecting $20 \mu \mathrm{g}(0.2 \mathrm{~mL})$ of Gonadorelin (Fertagyl, Intervet, Salamanca, Spain) immediately after AI.
Controlled suckling was applied to all does from 0 to 10 days post partum, by keeping the nest door closed and only opening it every $24 \mathrm{~h}$, at 12:00 h, to allow the kits to suck once a day. The day of AI (day 11 post partum) suckling was delayed until 17:00 h, 5-10 min before performing the AI. This made a 30-h mother-litter separation. From day 12 post partum (i.e. 1 day after AI) to weaning (30-35 days post partum) free suckling was allowed by keeping the nest door open. Litters were weighted on day 21 post partum, and mean weight of rabbit/ litter and mean weight of rabbit/group A or B were calculated. At 11-14 days after AI, all does were diagnosed for pregnancy by transabdominal palpation.

At weaning, rabbits were sent to an industrial farm to finish their growth, and during that period (i.e. 7-12 days before next partum) nests cleaning and disinfection operations were done in preparation for next parturition.

Parturitions took place mainly on the day 30 post $\mathrm{AI}$ and in the morning of day 31 . For those does not having given birth in the afternoon of day 31, parturition was induced by injecting subcutaneously 2 IU Oxytocin (Hormonipra, Hipra, Girona, Spain). After this treatment (applied to about $5 \%$ of the parturitions), labor generally commenced within 5-10 min and it was usually completed within $15 \mathrm{~min}$.

When all does had completed parturition, numbers of born alive and dead kits per litter were recorded. Afterwards litters were equalled to 10 kits with homogeneous rabbit size within litter. Exceeding kits were euthanatized by intraperitoneal injection of Sodium Pentobarbital (Dolethal, Vetoquinol, Madrid, Spain).

\subsection{Treatments}

The experiment was designed according to a $2 \times 2$ factorial model using the following treatments: (1) two lighting schedules 
(A or B) and (2) using or not oestrus synchronization hormonal treatment. The effects of those treatments on the reproductive performance were evaluated as: receptivity based on vulvar colour, fertility or kindling rates, litter size and number of young born dead, mean weight at 21 days post birth, mortality from 1 to 21 days post birth and number of weaned rabbits per litter.

(1) Two lighting schedules were compared: A vs. B.

Does submitted to lighting schedule A $(n=20)$ received a $12-\mathrm{h} \mathrm{L}$ (from 8:00 $\mathrm{h}$ to 20:00 h)/12-h D photoperiod until day 6 before AI, when photoperiod was suddenly changed to 16-h L (from 7:00 h to 23:00 h)/ 8-h D and maintained until day 0 (day of performing AI). In the 4 days following AI, 1-h $\mathrm{L}^{- \text {day }^{-1}}$ was reduced (i.e. the light was on from 8:00 h to 23:00 $\mathrm{h}$ the first day, from $8: 00 \mathrm{~h}$ to $22: 00 \mathrm{~h}$ the second day, from $8: 00 \mathrm{~h}$ to $21: 00 \mathrm{~h}$ the third day, and from $8: 00 \mathrm{~h}$ to 20:00 $\mathrm{h}$ the fourth day), so that the day 5 after AI, the initial 12-h L/12-h D photoperiod was re-established.

Does submitted to lighting schedule B $(n=20)$ received a $8-\mathrm{h} \mathrm{L}$ (from $12: 00 \mathrm{~h}$ to 20:00 h)/6-h D photoperiod until day 6 before AI, when photoperiod was changed to 16-h L (from 7:00 h to 23:00 h)/8-h D and maintained until day 0 . In the 4 days following AI, 2-h L·day ${ }^{-1}$ were reduced (i.e. the light was on from 8:00 h to 22:00 $\mathrm{h}$ the first day, from 9:00 $\mathrm{h}$ to 21:00 $\mathrm{h}$ the second day, from 10:00 h to 20:00 h the third day, and from 12:00 $\mathrm{h}$ to 20:00 $\mathrm{h}$ the fourth day), so that the day 5 after AI, the initial 8-h L/ $16-\mathrm{h}$ D photoperiod was re-established.

(2) The effect of using oestrus synchronization hormonal treatment (20 IU PMSG) was compared with the lack of hormonal treatment.

The four treatment groups, therefore, can be summarized as follows:

A/ PMSG $(n=60)$ : 20 does submitted to photoperiod $\mathrm{A} \times 3$ AIs each using PMSG;

B/ PMSG $(n=60)$ : 20 does submitted to photoperiod $\mathrm{B} \times 3$ AIs each using $\mathrm{PMSG}$; A/ no PMSG $(n=60)$ : 20 does submitted to photoperiod $\mathrm{A} \times 3$ AIs each without using PMSG;

B/ no PMSG $(n=60)$ : 20 does submitted to photoperiod $\mathrm{B} \times 3$ AIs each without using PMSG.

\subsection{Statistical analysis}

Data on total number (prolificity), number of young born dead, weight of litter at 21 days post birth, and number of weaned rabbits/litter were analysed using the GLM (General Linear Model) procedure of SPSS 10.0 software (SPSS Inc., Chicago, Illinois, USA), according to a linear model considering the effects of the lighting schedule ( 2 levels $=$ photoperiod $\mathrm{A}$ or $\mathrm{B})$, the oestrus synchronization hormonal treatment (2 levels = PMSG or no PMSG) and the interaction between them (Photoperiod $\times$ PMSG), and the differences between means were tested by Fisher F test. Data on sexual receptivity and kindling rates were analysed by Pearson Chi-square test including simultaneously the effect of both variables (photoperiod and PMSG use). Differences were considered statistically significant at the $p<0.05$ level.

\section{RESULTS}

Data corresponding to replacing does who had been just introduced in the experiment were not included, since those does had not been previously submitted to photoperiodic treatments. Therefore, the real number of AIs corresponding to each treatment group was lower than $n=60$.

Data on sexual receptivity of does expressed by the vulvar colour at AI is presented in the Table I. The PMSG treatment had a clear influence $(p<0.005)$ on does sexual receptivity. For both lighting schedules, when PMSG was used for oestrus synchronization, most of the females had a red 
Table I. Percentage of does having white, pink, red or purple vulva colour at AI in function of the photoperiod and PMSG oestrus synchronization treatments.

\begin{tabular}{lcccccccc}
\hline & \multicolumn{3}{c}{ Photoperiod A } & & \multicolumn{3}{c}{ Photoperiod B } \\
\cline { 2 - 4 } \cline { 7 - 8 } Receptivity & $\begin{array}{c}\text { PMSG } \\
(n=53)\end{array}$ & $\begin{array}{c}\text { No PMSG } \\
(n=56)\end{array}$ & $\begin{array}{c}\text { Total } \\
(n=109)\end{array}$ & & $\begin{array}{c}\text { PMSG } \\
(n=56)\end{array}$ & $\begin{array}{c}\text { No PMSG } \\
(n=55)\end{array}$ & $\begin{array}{c}\text { Total } \\
(n=111)\end{array}$ \\
\hline White (\%) & 0 & 0 & 0 & & 5.4 & 9.1 & 7.2 \\
Pink (\%) & 1.9 & 23.2 & 12.8 & & 3.6 & 30.9 & 17.1 \\
Red (\%) & 94.3 & 75 & 84.4 & & 89.3 & 58.2 & 73.9 \\
Purple (\%) & 3.8 & 1.8 & 2.7 & & 1.8 & 1.8 & 1.8 \\
\hline
\end{tabular}

vulva at AI (corresponding to a high sexual receptivity) (Tab. I), whereas without using PMSG, percentages of does with red vulva significantly decreased in favor of those having pink vulva. The photoperiod had not a statistically significant effect on sexual receptivity, although when not using PMSG, a tendency was seen $(p=0.076)$ for sexual receptivity to be lower under photoperiod B than under photoperiod A. The proportions of does showing white or pink vulvas (corresponding to a low sexual receptivity) at AI were higher in the females submitted to lighting schedule B than in those sub- mitted to lighting schedule A (Tab. I). On the contrary, the percentage of does with red vulva was higher among females submitted to photoperiod $\mathrm{A}$.

Data on kindling rates after AI obtained for the different treatments are presented in Table II. Kindling rates were not significantly influenced by the lighting schedule, the PMSG treatment or the interaction between them. Despite PMSG treatment had a significant influence on receptivity, this was not reflected on fertility. A difference in kindling rate of nearly $10 \%$ was observed between the two lighting programs when

Table II. Mean kindling rates (\%) of does having white, pink, red or purple vulva colour at AI in function of the photoperiod and PMSG oestrus synchronization treatments.

\begin{tabular}{|c|c|c|c|c|c|c|}
\hline \multirow[b]{2}{*}{ Receptivity } & \multicolumn{3}{|c|}{ Photoperiod A } & \multicolumn{3}{|c|}{ Photoperiod B } \\
\hline & $\begin{array}{l}\text { PMSG } \\
(n=53)\end{array}$ & $\begin{array}{l}\text { No PMSG } \\
(n=56)\end{array}$ & $\begin{array}{c}\text { Total } \\
(n=109)\end{array}$ & $\begin{array}{l}\text { PMSG } \\
(n=56)\end{array}$ & $\begin{array}{l}\text { No PMSG } \\
(n=55)\end{array}$ & $\begin{array}{c}\text { Total } \\
(n=111)\end{array}$ \\
\hline White (No. or \%) & $0 / 0$ & $0 / 0$ & $0 / 0$ & $1 / 3$ & $2 / 5$ & $\begin{array}{c}3 / 8 \\
(37.5 \%)\end{array}$ \\
\hline Pink (No. or \%) & $1 / 1$ & $\begin{array}{c}11 / 13 \\
(84.6 \%)\end{array}$ & $\begin{array}{r}12 / 14 \\
(86 \%)\end{array}$ & $2 / 2$ & $\begin{array}{c}14 / 17 \\
(82.4 \%)\end{array}$ & $\begin{array}{l}16 / 19 \\
(84 \%)\end{array}$ \\
\hline Red (No. or \%) & $\begin{array}{l}44 / 50 \\
(88 \%)\end{array}$ & $\begin{array}{c}37 / 42 \\
(88.1 \%)\end{array}$ & $\begin{array}{r}81 / 92 \\
(88 \%)\end{array}$ & $\begin{array}{l}43 / 50 \\
(86 \%)\end{array}$ & $\begin{array}{c}26 / 32 \\
(81.3 \%)\end{array}$ & $\begin{array}{c}69 / 82 \\
(84.5 \%)\end{array}$ \\
\hline Purple (No.) & $1 / 2$ & $1 / 1$ & $2 / 3$ & $1 / 1$ & $1 / 1$ & $2 / 2$ \\
\hline $\begin{array}{l}\text { Total Kindling rates } \\
\text { (\% or No.) }\end{array}$ & $\begin{array}{l}86.8 \% \\
(46 / 53)\end{array}$ & $\begin{array}{l}87.7 \% \\
(49 / 56)\end{array}$ & $\begin{array}{c}87.2 \% \\
(95 / 109)\end{array}$ & $\begin{array}{l}83.9 \% \\
(47 / 56)\end{array}$ & $\begin{array}{l}78.2 \% \\
(43 / 55)\end{array}$ & $\begin{array}{l}81.1 \% \\
(90 / 111)\end{array}$ \\
\hline
\end{tabular}


the does were not treated with PMSG (87.8\% vs. $78.2 \%)$, but such difference was statistically not significant ( $p=0.193$ ). As it was expected, does showing a white vulva at AI had the lowest conception rate $(37.5 \%)$ (Tab. II), and these appeared only under photoperiod $\mathrm{B}$, however, the number of does was too small (8/111) to make significant differences between both lighting schedules.

Neither the lighting schedule nor PMSG treatment had significant effect on the total number of newborn kits (Tab. III), and does receptivity did never influence prolificity, although the large difference in the number of animals per group may account for the lack of significance. The lighting schedule, however, but not the PMSG treatment, had a significant effect $(p<0.05)$ on the mortality at birth (Tab. IV). Litters housed under photoperiod A had a higher mean number of dead-born kits than those under photope$\operatorname{riod} \mathrm{B}(1.4 \pm 2.5$ vs. $0.6 \pm 1.3$ for $\mathrm{A}$ and $\mathrm{B}$, respectively). The mortality per litter from birth to days 21 , the weight of the litter at $21 \mathrm{~d}$, or the number of weaned rabbits per litter, however, were no different for litters submitted to both photoperiods.

Table V shows data on global productivity for the 4 treatments based on the total

Table III. Prolificity (Means \pm SD) of does having white, pink, red or purple vulva colour at AI in function of the photoperiod and PMSG oestrus synchronization treatments.

\begin{tabular}{lccccccc}
\hline & \multicolumn{3}{c}{ Photoperiod A } & & \multicolumn{3}{c}{ Photoperiod B } \\
\cline { 2 - 3 } \cline { 7 - 8 } Receptivity & $\begin{array}{c}\text { PMSG } \\
(n=53)\end{array}$ & $\begin{array}{c}\text { No PMSG } \\
(n=56)\end{array}$ & $\begin{array}{c}\text { Total } \\
(n=109)\end{array}$ & & $\begin{array}{c}\text { PMSG } \\
(n=56)\end{array}$ & $\begin{array}{c}\text { No PMSG } \\
(n=55)\end{array}$ & $\begin{array}{c}\text { Total } \\
(n=111)\end{array}$ \\
\hline White & 0 & 0 & 0 & & 12 & $12.5 \pm 3.5$ & $12.3 \pm 2.5$ \\
Pink & 7.0 & $9.3 \pm 4.1$ & $9.1 \pm 4.0$ & & $10.5 \pm 6.4$ & $10.5 \pm 3.3$ & $10.5 \pm 3.5$ \\
Red & $11.52 \pm 2.9$ & $11.1 \pm 2.84$ & $11.3 \pm 2.9$ & & $11.6 \pm 2.6$ & $10.9 \pm 2.9$ & $11.4 \pm 2.7$ \\
Purple & 12.0 & 9.0 & $10.5 \pm 2.1$ & & 15.0 & 15.0 & 15.0 \\
\hline Total & $11.4 \pm 2.9$ & $10.6 \pm 3.2$ & $11.0 \pm 3.1$ & & $11.7 \pm 2.7$ & $10.9 \pm 3.1$ & $11.3 \pm 2.9$ \\
\hline
\end{tabular}

Table IV. Mortinatality, mortality at 21 days, young growth and weaned rabbits in function of the photoperiod and PMSG oestrus synchronization treatments.

\begin{tabular}{|c|c|c|c|c|c|c|}
\hline & \multicolumn{3}{|c|}{ Photoperiod A } & \multicolumn{3}{|c|}{ Photoperiod B } \\
\hline & $\begin{array}{l}\text { PMSG } \\
(n=44)^{*}\end{array}$ & $\begin{array}{l}\text { No PMSG } \\
(n=49)\end{array}$ & $\begin{array}{c}\text { Total } \\
(n=93)\end{array}$ & $\begin{array}{l}\text { PMSG } \\
(n=47\end{array}$ & $\begin{array}{l}\text { No PMSG } \\
(n=43)\end{array}$ & $\begin{array}{c}\text { Total } \\
(n=90)\end{array}$ \\
\hline Mortality/litter at birth & $1.8 \pm 2.9$ & $1.0 \pm 2.0$ & $1.4 \pm 2.5^{\mathrm{a}}$ & $0.4 \pm 0.7$ & $0.7 \pm 1.7$ & $0.6 \pm 1.3^{\mathrm{a}}$ \\
\hline Mortality/litter at $21 \mathrm{~d}$ & $1.4 \pm 2.1$ & $1.8 \pm 1.8$ & $1.6 \pm 2.0$ & $1.2 \pm 1.9$ & $1.6 \pm 1.6$ & $1.4 \pm 1.8$ \\
\hline $\begin{array}{l}\text { Mean weight/rabbit } \\
\text { at } 21 \mathrm{~d}(\mathrm{~g})\end{array}$ & $345 \pm 0.6$ & $365 \pm 0.4$ & $355 \pm 0.5$ & $345 \pm 0.4$ & $358 \pm 0.5$ & $352 \pm 0.4$ \\
\hline $\begin{array}{l}\text { Mean weaned } \\
\text { rabbits/litter }\end{array}$ & $8.4 \pm 2.2$ & $8.2 \pm 1.8$ & $8.3 \pm 2.0$ & $8.8 \pm 1.9$ & $8.4 \pm 1.6$ & $8.6 \pm 1.8$ \\
\hline
\end{tabular}

* Two does died during parturition.

${ }^{a}$ Means in a row are different $(p<0.05)$. 
Table V. Global productivity (number of weaned rabbits per 100 inseminated does) in function of the photoperiod and PMSG oestrus synchronization treatments.

\begin{tabular}{lcccccccc}
\hline & \multicolumn{3}{c}{ Photoperiod A } & & \multicolumn{3}{c}{ Photoperiod B } \\
\cline { 2 - 3 } \cline { 7 - 8 } & PMSG & No PMSG & Total & & PMSG & No PMSG & Total \\
\hline $\begin{array}{l}\text { Weaned rabbits/100 } \\
\text { AIs (No.) }\end{array}$ & 730.8 & 714.9 & 722.9 & & 738.3 & 656.9 & 697.5 \\
\hline
\end{tabular}

number of weaned kits/100 AI (mean number of weaned rabbits $\times$ kindling rate). When using photoperiod A, PMSG hardly increased productivity $(+0.16$ weaned rabbits per inseminated doe), however, when using photoperiod $\mathrm{B}$, PMSG increased productivity in nearly one weaned rabbit $(+0.8)$ per inseminated doe.

The highest productivity was obtained with photoperiod B and using PMSG, however, the difference between that treatment and photoperiod A no using PMSG was only of +0.23 weaned rabbits per inseminated doe.

\section{DISCUSSION}

The sexual activity of rabbits, in natural conditions, is maximal during the long-day seasons. By artificially increasing the daylight length in rabbit farms does sexual receptivity and fertility may be improved. Continuous lighting programs of 14 or $16 \mathrm{~h}$ light per day all year round [26, 27] seem to have a positive effect on does reproduction. Moreover, increasing the daylight hours few days before $\mathrm{AI}[15,21]$ or using interrupted lighting programs $[3,26]$, does receptivity and fertility seem to be promoted. However, productivity in terms of litter viability and weaning weight not always could be improved $[15,21]$ probably due to an inverse relationship between daylight hours and feed consumption or suckling habits [22].

In the present study, a sudden increase of daylight hours 6 days before performing
AI was an effective method to synchronize oestrous in lactating does. For the two photoperiods used in this study, does sexual receptivity improved significantly when PMSG was used, although it was not reflected on fertility and prolificity, which were similar for the two lighting schedules and regardless of the PMSG treatment.

The colour of the vulva is an indicator of receptivity, which is determined by the serum oestrogen levels secreted by the growing ovarian follicles [10]. Red and purple vulvar colours are believed to correspond to maximal receptivity and fertility in lactating does [20]. In the present study, we did not observe differences in fertility and prolificity between does with pink or red vulvar colour (Tabs. II and III), and only a very small number of females exhibited a purple vulva. Potential differences in fertility and prolificity between does with pink, red or purple vulvar colours may have not been detected due to the high difference in the number of animals per group (Tab. II), and/or due to the subjective nature of the vulva colour classification method. Significant lower fertility, however, was found among females showing white vulvar colour at AI. This group of females were thought to have small ovarian follicles not ready to ovulate or too immature oocytes to be fertilized. These results, although in a small number of females, confirm those of TheauClément and Roustan [20], who found that less than $35 \%$ of females with a white vulva were fertile, as opposed to $70 \%$ with a red vulva. It is interesting to note that 
females with a white vulva, supposedly non receptive, only were seen among the group of does submitted to $8 \mathrm{~h}$ of continuous daylight, and within this group, also among the does that received PMSG treatment. Therefore, using or not PMSG, $12 \mathrm{~h}$ of continuous daylight seemed to be more effective for oestrous synchronization than $8 \mathrm{~h}$ of continuous daylight. This is consistent with a higher sexual stimulation known to be naturally experienced by rabbits during longday seasons [8], and with results from previous studies [12, 26] where a favourable effect of long artificial days on the sexual receptivity of the does was confirmed. Some authors $[15,21]$ found that suddenly increasing the day-length in 6-8 h of light from 5-8 days before AI, significantly improved sexual receptivity of the does in comparison with constant lighting programs. In the present study, a sudden increase in daylength of only 4 hours (from $12 \mathrm{~h}$ to $16 \mathrm{~h}$ ) resulted in a better oestrous synchronization than an increase of 8 hours (from $8 \mathrm{~h}$ to $16 \mathrm{~h}$ ). Perhaps such a sharp difference in light hours from one day to the next one was too stressful, exceeding the level of stimulation required for optimal physiological response.

PMSG treatment has been reported to increase the litter size in about one rabbit per litter $[6,13]$, although it was sometimes accompanied by a higher mortality at birth $[1,14]$. We also obtained a higher litter size (one kit more) when using PMSG, however, in our study mortality at birth resulted to be affected by photoperiod but not by PMSG treatment (Tab. IV). Mortality at birth was higher under a continuous 12-h daylight than under $8 \mathrm{~h}$ of daylight. The reason why 4 hours more of light per day caused an increase in mortality of about one kit per litter is not clear. Whether photoperiod may interfere in some way with mechanisms initiating parturition is not known. If so, such interference could be related to a minor or delayed release of oxytocin at parturition, prolonging its active phase, but it has to be proved.
There seems to be a direct relationship between the hours of darkness and the level of feed consumption and the resulting growth rates $[15,22,26]$. In this study, survival of the young rabbits and the weight of the litter at 21 days were not influenced by photoperiod, suggesting that milk production and feeding behaviour of the young rabbits were similarly affected by the two lighting programs. Bonanno et al. [4] reported that lactating does treated with PMSG showed a reduction in milk production, probably due to an antagonistic effect of this hormone on prolactin secretion. In the present study, the weight of the litter at 21 days, age at which rabbits weight only depends on milk production and suckling frequency, was statistically similar for all the litters registered, as well as the number of weaned rabbits per litter.

Separation of mothers from their litters for a 24-48-h time period before AI is another of the biostimulation methods used for inducing sexual receptivity and improving fertility of lactating does $[2,16,25]$. It is believed that, during the separation period, prolactin secretion is reduced and its antagonistic effect on gonadotrophin release could be suppressed [18]. A 36-48-h period of doe-litter separation has been found to be more effective than a 24-h period [2], and the beneficial effect on fertility seems to be more pronounced when applied on free nursing does than on controlled nursing does, probably because controlled nursing acts as a regular 24-h doe-litter separation [5].

In the present study, a $30-\mathrm{h}$ period of mother-litter separation before AI was applied to all does. Since the does were kept under controlled nursing until the day of AI, such separation period was actually a 6-h delay of the suckling. This punctual stress by itself may have not exerted a notorious effect on does sexual receptivity. However, oxytocin released during the suckling may have contributed to improve the AI results by inducing uterine contractions, thus, enhancing the sperm transport into the 
female genital tract [18]. The effects of the mother-litter separation may have influenced the does response to the lighting programs and/or PMSG treatment applied.

From a strictly statistical view point, the present results indicated that the two lighting schedules compared here had similar effects on the reproductive performance of lactating does (with the exception of mortality at birth), and that PMSG, independently of the photoperiod used, improved oestrous synchronization of does but not kindling rates or prolificity. However, when analysing the global productivity in terms of weaned rabbits per 100 inseminated does (Tab. V), it appears that when using the lighting schedule A, the PMSG treatment could be omitted without seriously affecting does productivity, whereas when using the lighting schedule B, productivity would be considerably impaired without using PMSG. This difference might indicate that an interaction between the photoperiod and the PMSG treatment could have influenced the kindling rate, despite the fact that such interaction was not detected in this study probably due to an insufficient number of animals per group.

In conclusion, our results suggest that photoperiod $\mathrm{A}$ induces and synchronises oestrous in lactating does and that does fertility and productivity seem not to be impaired without using PMSG. Further studies, involving a higher number of animals and a higher number of insemination cycles per animal, are needed to confirm these results and to determine if at a long term, the stimulatory effect of photoperiod in combination with other biostimulation methods allow to avoid the use of PMSG without affecting does productivity.

\section{ACKNOWLEDGEMENTS}

The study was supported by Xunta de Galicia (Plan Gallego de Investigación y Desarrollo Tecnológico, Proyecto Ref. 1999/CG321) and by Conejos Gallegos, COGAL S.L.

\section{REFERENCES}

[1] Alabiso M., Bonanno A., Alicata M.L., Portolano B., Trattamento "differenziato" con PMSG su coniglie inseminate artificialmente, Riv. Conigliocultura 31 (1994) 25-30.

[2] Alvariño J.M.R., Del Arco J.A., Bueno A., Effect of mother-litter separation on reproductive performance of lactating rabbit females inseminated on day 4 or 11 post partum, World Rabbit Sci. 6 (1998) 191-194.

[3] Arveux P., Troislouches G., Influence d'un programme lumineux discontinu sur la reproduction des lapines, $6^{\text {es }}$ Journées de la Recherche Cunicole, La Rochelle, 1994, Vol. 1 , pp. 121-126.

[4] Bonanno A., Alabiso M., Alicata M.L., Effetti del trattamento sincronizzante con PMSG su coniglie inseminate artificialmente, Riv. Coniglicoltura 28 (1991) 29-32.

[5] Bonanno A., Alabiso M., Di Grigoli A., Alicata M.L., Montalbano L., Effect of a 48-hour doelitter separation on performance of free or controlled nursing rabbit does, 7th World Rabbit Congress, Valencia, 2000, Section Reproduction and Reproductive Physiology, pp. 97-103.

[6] Bourdillon A., Chmitelin F., Jarrin D., Parez V., Rouillere H., Effect of PMSG treatment on breeding results of artificially inseminated rabbits, J. Appl. Rabbit Res. 15 (1992) 530-537.

[7] Boyd I.L., Effect of photoperiod and melatonin on testis development and regression in wild European rabbits (Oryctolagus cuniculus), Biol. Reprod. 33 (1985) 21-29.

[8] Boyd I.L., Effect of daylength on the breeding season in male rabbit, Mamm. Rev. 16 (1986) 125-130.

[9] Canali C., Boiti C., Castellini C., Battaglini M. Zampini D., Effetto di immunizzazione in coniglie trattate ripetutamente con PMSG. $2^{\circ}$ Meeting sullo studio della efficienza riproduttiva degli animali di interesse zootecnico, Bergamo, 1989, pp. 103-108.

[10] Castellini C., Recent advances in rabbit artificial insemination, 6th World Rabbit Congress, Toulouse, 1996, Vol. 2, pp. 13-26.

[11] Hammond J., Marshall F.H.A., Reproduction in the rabbit, Ed: Olivier and Boyd, Edinburgh, 1925, 210 p.; cited by: Theau-Clément M., Castellini C., Maertens L., Boiti C., Biostimulations applied to rabbit reproduction: Theory and practice, World Rabbit Sci. 6 (1998) 179-184.

[12] Harris D.J., Cheecke P.R., Patton N.W., Effect of diet, light and breeding schedule on rabbit performance, Proc. West. Sect. Amer. Soc. Animal Sci. 33 (1982) 190

[13] Maertens L., Luzi F., Note concerning the effect of PMSG stimulation on the mortality rate at birth and the distribution of litter size in a.i. does, World Rabbit Sci. 3 (1995) 57-61. 
[14] Maertens L., Okerman F., De Groote G. Moermans R., L'incidence de deux méthodes de traitement hormonal sur le comportement sexuel et la fertilité de jeunes lapines, Rev. Agric. 1 (1983) 167-174.

[15] Mirabito L., Galliot P., Souchet C., Effet de l'utilisation de la PMSG et de la modification de la photopériode sur les performances de reproduction de la lapine, $6^{\text {es }}$ Journées de la Recherche Cunicole, La Rochelle, 1994, Vol. 1, pp. 169-178.

[16] Pavois V., Le Naour J., Ducep O., Perrin G., Duperray J., Une méthode naturelle pour améliorer la réceptivité et la fertilité des lapines allaitantes en insémination artificielle,

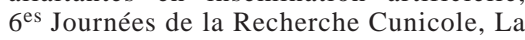
Rochelle, 1994, pp. 528-535.

[17] Rafay J., Influence of photoperiodic intervals on biochemical and reproduction traits in broiler rabbit populations, J. Appl. Rabbit Res. 15 (1992) 495-498.

[18] Theau-Clément M., Advances in biostimulation methods applied to rabbit reproduction, 7 th World Rabbit Congress, Valencia, 2000, Section Reproduction and Reproductive Physiology, Main paper $C$.

[19] Theau-Clément M., Lebas F., Effect of a systematic PMSG treatment 48 hours before artificial insemination on the productive performance of rabbit does, World Rabbit Sci. 4 (1996) 47-56.

[20] Theau-Clément M., Roustan A., A study on relationships between receptivity and lactation in the doe, and their influence on reproductive performances, J. Appl. Rabbit Res. 15 (1992) $412-421$.
[21] Theau-Clément M., Poujardieu B., Bellereaud J., Influence des traitements lumineux, modes de reproduction et états physiologiques sur la productivité de lapines multipares, $5^{\text {es }}$ Journées de la Recherche Cunicole, Paris, 1990, Tome 1, comm. 7.

[22] Theau-Clément M., Castellini C., Maertens L. Boiti C., Biostimulations applied to rabbit reproduction: Theory and practice, World Rabbit Sci. 6 (1998) 179-184.

[23] Theau-Clément M., Lebas F., Poujardieu B., Mercier P., Effet de différentes doses de PMSG sur l'induction de la réceptivité sexuelle et la productivité des lapines conduites en insémination artificielle, $7^{\text {es }}$ Journées de la Recherche Cunicole, Lyon, 1998, pp. 221-224.

[24] Theau-Clément M., Lebas F., Drion P., Beckers J.F., Evolution de la production d'anticorps antiPMSG en fonction de la dose et du nombre d'injections. Relation avec la productivité des lapines, $7^{\text {es }}$ Journées de la Recherche Cunicole, Lyon, 1998, pp. 225-228.

[25] Theau-Clément M., Poujardieu B., Mercier P., Influence d'une séparation mère-jeunes, pendant les 24 heures précédant l'insémination, sur les performances de reproduction des lapines et la croissance des lapereaux, $8^{\text {es }}$ Journées de la Recherche Cunicole, Paris, 1999, pp. 163-166.

[26] Uzcategui M.E., Johnston N.P., The effect of 10,12 and 14 hour continuous and intermittent photoperiods on the reproductive performance of female rabbits, J. Appl. Rabbit. Res. 15 (1992) 553-559.

[27] Walter M.R., Martinet L., Moret B., Thibault C., Régulation photopériodique de l'activité sexuelle chez le lapin mâle et femelle, Arch. Anat. Histol. Embryol. 51 (1968) 773-780. 